\title{
Study on Application-oriented Talent Training Model of Public Security Colleges in Transition Period
}

\author{
GAO Na \\ Vocational Education College \\ Liaoning Police College \\ Dalian 116036, Liaoning

\begin{abstract}
The ministry of education vice-minister Lu Xin said in the end of March 2014, how to solve the structural contradiction of employment in China is the core of education reform. The breach of the education reform is the modern vocational education system, and training of talents is technical skilled talents. In the future, China will make the construction of modern vocational education system as the breakthrough point. We must implement the strategic adjustment of education structure, and adjust the focus on high school and higher education stage. According to the request from the ministry of education, in 2014 the total of 600 colleges and universities will finish transformation to vocational education. For public security, the most professional particularity of colleges and universities, training applied police officers, realize from the academic to the vocational educational change is inevitable. This article was based on such a background. The vocational education in the working process of the systematic education theory is introduced into the public security education. The way to the positioning of talent training, talent training, teaching mode innovation and teachers construction four aspects to explore the transformation of the public security colleges and universities of applied talents training mode.
\end{abstract}

Keywords- Working Process Systematization; Public Security Education; Transformation; Talent Training

\section{INTRODUCTION}

In March 22, 2014, Vice Minister of Education Lu Xin disclosed at China Development Forum that, the Ministry of Education transform over 600 local undergraduate into technology application and vocational education type. Lu proposed new undergraduate colleges and universities should develop as application undergraduate, and change the old path of following academic talents cultivating, so as to achieve the transformation of new undergraduate colleges and universities into higher occupation education. For public security colleges, to cultivate "application-oriented" police officers, and construct " application-oriented" teaching mode, is an important content of teaching reform of our country's education in police colleges, and is also an important measure to implement the strategy of talent strong school. In this paper, based on working process systematization educational theory, starting from the present situation and problems training mode of public security talents education at the present stage of our country, discuss the application-oriented talent training model of public security colleges in transition period.

\section{WORK PROCESS EDUCATIONAL THEORY}

Work process educational theory is originated from vocational education. In Germany in the 1990s, against the drawbacks of traditional vocational education divorced from the real work world, this theory was proposed by the famous vocational education scholar professor Rauner and his team, on the basis of a series of research results. After proposed, this theory was quickly recognized by German academics, and become the theoretical guidance of German vocational education reform. Work process educational theory was introduced into China in the early twenty-first century, mainly applied in occupation education system, but not in public security education.

Compared with traditional vocational education, the guiding ideology of work process educational theory is to cultivate students' ability of participating in the construction work of the world; courses content transformed from professional knowledge into work process knowledge; course construction transformed from qualification research into labor occupational scientific research; teaching methods transformed from traditional spoon into oriented teaching methods.

\section{APPLICATION-ORIENTED TALENT TRAINING MODEL BASED ON WORK PROCESS EDUCATIONAL THEORY}

\section{A. Talent Cultivation Orientation}

\section{1) Public Security Sector Demand}

Application-oriented talent training model based on work process educational theory should be work process-oriented, and taking public security sector demand as the center, that is, to train police talent that public security department really needed. However, to a certain extent, the existing police education personnel training orientation has departed from this standard. The main reason is, in the public security education mode, police education personnel training orientation take the education department for examination and approval of professional or professional direction as the standard, which leads to police talent stereotyped in different 
police institutions, cannot meet the actual needs of the local public security department. Actually, the focus of public security work in different areas and different period is different, and the type of talent needed is also different. In addition, for different crime type, we should cultivate appropriate personnel.

\section{2) nnovative Ability Cultivation}

In the guiding ideology, application-oriented talent training model based on work process educational theory should focus on the cultivation of students' innovation ability. With the development of the management theory, the public security organization management mode changes to some certain degree, from scientific management to knowledge management. In order to improve their service ability and efforts to fight crime, public security organization begins to pay attention to mobilizing the enthusiasm of police work, to provide a stage and the space for the development of their potential. University period is the best time for mining a personal potential, so it calls for police talent cultivated based on work process educational theory. Only the ability to adapt to the work of public security is far not enough, it also need innovation ability. That is to say, police education must consciously promote their positive impact on the development of the ability to fight crime and public security work, so as to achieve transformation from adapts ability to innovation ability.

\section{3) Ideological and Political Education}

Police is law and order administration with safeguard national security and maintain social order as the main task. This attribute determines that police colleges in personnel training must put ideological and political education as a major task. Security industry don't allow politically biased police, otherwise it will bring great obstacles to police work. Therefore, making efforts to strengthen students' literacy and political theory, cultivation students' loyalty and compliance, is the fundamental always adhere to the orientation of talent cultivation in public security colleges.

\section{B. Talent Cultivation Way}

\section{1) College and Board Joint Education Model}

The primary approach of application-oriented talent training model based on work process educational theory is school and board joint and police and science combined education model, solving the problem of traditional educational theory disconnected with public security practice. Change the Single mode that the traditional public security education only rely on the public security colleges, and bring public security public security practice into the classroom. Take full advantage of the public security leading real teaching, and extend the operational guidance from public security department to teaching sources, allowing students exposure to future job content in college.

Currently, police colleges across the country are striving to strengthen school and board joint education model. Liaoning Police College coordinated with public security departments has put forward the model "For Integration", that is, integrated professional training program, integration teacher and instructor team, integrated teaching and training environment and integrated scientific direction, achieving the goal of complementary advantages and resource sharing. Liaoning Police College has established 41 off-campus practice bases in some Liaoning province public security business sector, municipal public security bureau and so on. It not only provides a professional channel for reserve officer's practice, but also provides security for teachers carrying out the public security business credentials exercise.

2) Colleges Exchange Joint Education Model

The second approach of application-oriented talent training model based on work process educational theory is colleges exchange joint education model, solving the problems of students' weak cultural foundation and lack of humanities in public police colleges. Traditional public security education students focus on theoretical and operational knowledge of public security, while ignore the humanities education, which causes public security colleges graduates difficult to grasp the rules of public security work in practice. Colleges exchange refers to realizing combination of public security colleges and local colleges. We can adopt " $1+2+1$ " model, which means students first receive 1 years of basic cultural knowledge learning in local university, and then receive 2 years of police professional knowledge learning in public security colleges, and finally take part in public security departments practice combat for the last 1 year.

\section{3) Overseas Cooperation Education Model}

The third approach of application-oriented talent training model based on work process educational theory is overseas cooperation education model. Western police education is earlier than China, and there is advanced place, no matter educational philosophy or education methods, which can be referenced by us. One significant sign of application-oriented talent training model based on work process educational theory is to butt up personnel training and industry needs. For Liaoning Police College, since located in Dalian, with high degree of openness, where foreign businessmen from Japan, South Korea, Russia and other places are so many, so foreign police liaison and enforcement work has become increasingly burdensome and complex. Strengthening cooperation with overseas police colleges, can send out our students and teachers, or welcome the teachers from overseas to cultivate international police affairs.

\section{Teaching Mode Innovation}

\section{1) Major Setting Based on Work Process} Systematization

In the traditional public security education mode, major setting in public police colleges took education authorities majors as standard, which to some extend lead to highsimilarity of majors in most public security colleges. Major setting based on work process systematization should be employment-oriented. On the one hand, we should carry out major investigation, to know about the local security situation within a period, crime type and community needs, so as to conduct targeted majors. On the other hand, before setting up a major with regional characteristics, we must invite some experts for demonstration, to ensure its viability. 


\section{2) Curriculum System Based on Work Process} Systematization

Curriculum system based on work process systematization consists of two elements: course content selection and course content sorting.

Course content selection should pay attention to two aspects. One is the curriculum object oriented, that is, the level of intelligence and thinking characteristics of police college students. Most of police college students should have imaginal thinking. For imaginal thinking students, to master and apply some knowledge, they must be associated with a certain environment and background. Practice teaching system of Liaoning Police College is to create an environment conducive to the image of the thinking of the audience, environment and background to master and apply the knowledge. Another aspect is curriculum content basic categories. The public security education and training of personnel should be strategy level applied talents, rather than experience level, focus on "how". Therefore, public police college curriculum content should take procedural knowledge as emphasis and declarative knowledge as supplement.

Course content sorting should pay attention to two aspects. First, work process is systematic, including professional competence, method competence and social competence. It requires teachers learn to learn, learn to work, and learn to get along with others. Second, work process is in a state of constant motion, containing six elements of objects, content, tools, organization, product and environment. Third, working process structure is relatively fixed, containing six phases of information, decision-making, planning, implementation, inspection and evaluation. No matter how complex the work process is, we should be based on the six steps to complete it. For example, in the process of pursuing an escaped prisoner, public security personnel firstly need to confirm prisoner's personal information, including height, appearance, and even psychological characteristics, and then make decisions according to the information received.

3) Course Design Based on Work Process Systematization

The first step is job task analysis. According to public security professional jobs and job groups, implement typical tasks analysis. We can make use of brainstorming, expert interviews, Gordon, Delphi method and other statistical methods, to screen out typical tasks, including realistic tasks and possible future tasks.

The second step is action areas induction. For the typical tasks selected in the first step, carry out further induction, to form action areas that meet the real needs of public security. In this step, the focus is to meet the real needs of public security.

The third step is learning area conversion. That is, convert the action areas in the second step into courses. Courses design would not only consider the needs of public security, but also need to integrate education factor. We should not only follow the laws of career growth, but also follow the law of cognitive learning. So we need to make learning area conversion, that is, course system sorting.
The fourth step is learning situation design. Learning situation design is about specific teaching process. According to public security features and actual characteristics of students' thinking, refine learning field as the theme of learning situation.

4) Teaching Method Based on Work Process Systematization

Teaching method based on work process systematization should make conversion that form teaching center to student demand center, and aim at students' innovation. Change the traditional teaching methods of public security education, and vigorously carry out case teaching method, practical teaching method, situational teaching method and some other teaching method close to the public security working process. For example, case teaching method advocated in the first national teaching skills competition in public security colleges, making students lay a solid theoretical foundation and enhancing the ability to analyze problems and to solve the problem. Practical teaching method moves the teaching process from classroom to the actual site, to develop traffic management, security management, investigation and interrogation, major events security and other courses, allowing students to contact a real public security work. Situational teaching method is more intuitive. By multiple episodes show, teachers can simulate real-world scenarios for teaching

\section{TEACHERS CONSTRUCTION}

\section{A. Build a Double-qualified Teachers Team}

Double-qualified teachers based on work process systematization refers to "double quality type" teachers, synchronously with scientific research quality and frontline police quality, so it requires public police colleges make effort to cultivate the internal teacher police combat capability. First, newly recruited professional teachers should take part in testing exercise in public police department for more than one year, and receive teaching post only after passing the assessment. Because most of the teachers in public police colleges are candidates from local colleges, who have rich theoretical knowledge and scarcity practical experience, testing exercise will not only help them to understand the security business, but also enrich their practical experience, which is of great benefit for their future practical teaching. Second, carry out police practice capacity building project, ask the teachers to take the testing exercise, short-term internships, research way to join in practical exercise, to improve teachers' knowledge structure and ability structure, and effectively improve the ability and level of the teachers' teaching practice of public security.

\section{B. Construct Instructors into the Classroom System}

To enhance teachers construction based on work process systematization, public police colleges can try to introduce instructors into the classroom system. Frontline police really knows combat need what kind of talent, so in their lectures, it is full of practical contents, and furthermore it is also more targeted for personnel training. Public police colleges should strictly select instructors from counterpart post, from the 
perspectives of academic qualifications, work experience and the ability of language expression, etc. In addition, public police colleges can strive for superior leadership organization's political support, and encourage frontline police to make communication in police colleges.

\section{CONCLUSIONS}

talent training mode is explored the transformation of the public security colleges and universities of applied talents training mode through teaching mode innovation and teachers construction and so on four aspects to build a Double-qualified Teachers Team, Construct Instructors into the Classroom System

\section{ACKNOWLEDGEMENT}

Funding: Phased research of Liaoning Province Educatio $\mathrm{n}$ and Scientific Projects "study on application-

oriented police talent training mode based on work process $\mathrm{s}$ ystematization"(JG14EB156), host: Gao Na.

\section{Reference}

[1] Fu Guo-Liang. Practice and Exploration excellent education and training of police personnel [J]. Police Education, 2012(01), 48-51.

[2] Li Fu-Chao. In Police Colleges "combat-type" training mode architecture [J]. Liaoning Police Academy, 2014(01), 106-109.

[3] Ma Shun-Cheng, Yu Qun. Thinking in Public Security College Professional Training Mode [J]. Security Science Journal- Journal of Zhejiang Police College, 2014(02), 49-51.

[4] Jiang Da-Yuan. Discussion on the systematic design of higher vocational education courses- Interpretation of the work process of systematic curriculum development [J]. China Higher Education Research, 2009(04, 66-70. 